\title{
A functional study of caustic strictures of the esophagus in children
}

E.A.L. Da-Costa-Pinto ${ }^{1}$, T.K. Dorsa ${ }^{1}$, A. Altimani ${ }^{2}$, N.A. Andreollo, S.R. Cardoso ${ }^{1}$, D.J. Morais ${ }^{3}$ and J.M. Bustorff-Silva ${ }^{4}$

\author{
Departamentos de ${ }^{1}$ Pediatria, ${ }^{2}$ Anatomia Patológica, and Disciplinas de \\ ${ }^{3}$ Gastrocirurgia and ${ }^{4}$ Cirurgia Pediátrica, Departamento de Cirurgia, \\ Faculdade de Ciências Médicas, Universidade Estadual de Campinas, \\ Campinas, SP, Brasil
}

\section{Correspondence \\ E.A.L. Da-Costa-Pinto \\ Condomínio Lagoa Serena \\ Estrada da Rhodia, km 15, Casa 28 \\ 13085-902 Campinas, SP \\ Brasil \\ Fax: +55-19-3287-0432 \\ E-mail: elicostapinto@uol.com.br}

Research supported by FAEP (No. 1282/02). T.K. Dorsa is the recipient of a PIBIC/CNPq fellowship.

Publication supported by FAPESP. $\ldots \ldots \ldots \ldots \ldots \ldots$

Received September 16, 2003 Accepted July 12, 2004

\begin{abstract}
The objective of the present study was to assess esophageal motor function in 21 children $(7.5 \pm 2.9$ years $)$ with caustic strictures. Esophageal manometry was performed using a water-infusion system interfaced with a polygraph and displayed on a computer screen. The data were compared with those obtained from 9 healthy children. Radionuclide transit was determined by studying deglutition of a single bolus of ${ }^{99 \mathrm{~m}} \mathrm{Tc}$ pertechnetate in $10 \mathrm{ml}$ of water. Non-peristaltic low-amplitude and long-duration waves were the most common findings detected in patients with strictures longer than $20 \%$ of esophageal length $(\mathrm{N}=11)$. Compared with the control group, these patients presented lower mean amplitude and longer mean duration of waves $(24.4 \pm 11.2$ vs $97.9 \pm 23.7 \mathrm{mmHg}, \mathrm{P}<0.05$, and $6.7 \pm 2.4$ vs $1.6 \pm 0.1$ $\mathrm{s}, \mathrm{P}<0.05$, respectively). Six patients presented low-amplitude waves just below the constricted site. Ten children presented delayed esophageal transit. There was an association between dysphagia and abnormalities on manometry $(\mathrm{P}=0.02)$ and between symptoms and scintigraphy data $(\mathrm{P}=0.01)$. Dysphagia in caustic strictures is due to esophageal motility abnormalities, which are closely related to the scarred segment.
\end{abstract}

Key words

- Caustic esophagitis

- Esophageal dysfunction

- Manometry

- Esophageal transit

\section{Introduction}

Infants and young children often accidentally ingest caustic agents. Most accidents occur because children have access to strong household cleaners that were stored inappropriately in food and drink containers. Latin American children are more vulnerable because caustics are commercially available and there is no legislation requiring the manufacture of less concentrated products. A recent survey has reported up to 100 acci- dents per year at a single Health Unit in Montevideo, Uruguay, with most accidents involving children who had ingested sodium hydroxide or lye solutions (1).

Ingested liquid alkaline agents cause injuries to the entire esophagus, destroying even the full thickness of the organ wall (2). A few months after the accident, different degrees of esophageal damage may be identified in 22 to $58 \%$ of affected children (3). A deep circumferential burn involving muscles heals by fibrosis, causing a stricture that will 
give origin to a long-term health problem. In Brazil, most endoscopic therapeutic procedures at Pediatric Centers consist of esophageal dilatations of chronic caustic strictures (4).

Dysphagia is the most common symptom and in many cases it is a consequence of the esophageal narrowing. However, it has been observed that swallowing difficulties are not always related to the esophageal stricture and that motility abnormalities also play an important role as a cause of the symptom $(5,6)$.

We report here the results of esophageal motility studies carried out on children with esophageal strictures caused by severe caustic accidents.

\section{Patients and Methods}

Fifty-eight children with esophageal caustic burns were admitted to the University Hospital of the School of Medical Sciences, State University of Campinas, Campinas, SP, Brazil, over a 10-year period (19912000). Of these, $52 \%(\mathrm{~N}=30)$ have been treated with a dilatation protocol involving upper digestive endoscopy for stricture formation and obstruction of the esophageal lumen. Esophageal motility was studied in 21 of these children, 6 patients were not studied for having a guide thread for bouginage treatment and three children were lost follow-up because of moving to another city during the study period.

All patients had ingested sodium hydroxide. Age at the time of the accident ranged from 1.2 to 13.4 years $(2.8 \pm 2.6$ years, mean $\pm \mathrm{SD})$. At the time of the functional study, patients were aged 4.3 to 15.5 years $(7.5 \pm$ 2.9 years, mean $\pm \mathrm{SD}$ ). All occurrences were accidental, except for one girl who had attempted suicide.

Immediately after the accident, patients were hospitalized and intravenous fluid and a prophylactic antibiotic were administered. Those who were unable to swallow received total parenteral nutrition, had a nasogastric tube placed under endoscopy guidance, or underwent emergency gastrostomy. An esophagogastroduodenoscopy was performed within $48 \mathrm{~h}$ of caustic ingestion to determine the severity of injury. Damage was considered slight when it consisted of mucosal erythema, moderate when there were non-circumferential superficial ulcerations, and severe when erosions or ulcerations were confluent, deeper than in moderate cases, and included the entire esophageal circumference.

During the study period, 9 patients underwent regular esophageal dilatations. The remaining children had undergone esophageal dilatations in the past. Sixteen patients had undergone a fundoplication before the functional studies because of a reflux index above $4 \%$ in prolonged $\mathrm{pH}$ monitoring and/ or erosive peptic esophagitis in an upper digestive endoscopy. Two patients (number 1 and 6 in Table 1) needed esophageal replacement surgery performed after the functional study. Esophageal fragments from these two patients were fixed in formol, embedded in paraffin, sectioned transversely, and stained with hematoxylin-eosin.

Functional studies were performed 2 days apart. In patients undergoing dilatation, the studies were scheduled 2 weeks after the procedure. An upper digestive endoscopy was performed during the two-week period before the functional studies for an eventual diagnosis of peptic esophagitis. Anatomical or histological signs of peptic esophagitis were not diagnosed in these upper digestive endoscopy procedures.

\section{Functional studies}

Motility studies were performed using a water-infusion manometry system with a lowcompliance pneumohydraulic capillary-infusion pump. The catheter (available from Arndorfer Medical Specialties, Greendale, WI, USA) consists of four capillary tubes 
with an outer diameter of $3.0 \mathrm{~mm}$ (orifices placed $3 \mathrm{~cm}$ apart) used for children under 5 years old, or of $3.5 \mathrm{~mm}$ (orifices placed $5 \mathrm{~cm}$ apart) for older children. Each capillary was connected to a polygraph and data were displayed on a PC (IBM $\left.{ }^{\mathrm{TM}}\right)$, using a specific software (Gastrosoft ${ }^{\mathrm{TM}}$, Polygram Upper $\mathrm{GI}^{\mathrm{TM}}$, version 6.40, Synectics Medical ${ }^{\mathrm{TM}}$, Stockholm, Sweden).

Esophageal manometry was performed after a 6-h fast. Patients were studied while lying on their left side and received no sedatives. The catheter was introduced through the nostril until the four side holes were inside the stomach. After 15 min for patient adaptation, the catheter was pulled out in $0.5-\mathrm{cm}$ steps and the lower esophageal sphincter pressure was measured (through the four orifices) using the station pullthrough technique. Sphincter pressure was measured from gastric baseline to end-expiration pressure at the highest resting pressure (usually immediately before the pressure inversion point). The mean of the pressures measured at the four orifices was taken to be the lower esophageal sphincter pressure.

To evaluate the esophageal body, contraction waves were induced by swallowing 3 to $5 \mathrm{ml}$ of water. The amplitude and duration of contraction waves for each individual were calculated as the mean of 10 swallows. A swallowing complex was considered to be measured only when it started at least $20 \mathrm{~s}$ after the previous one. Contraction wave amplitude was measured $3 \mathrm{~cm}$ above the proximal end of the lower esophageal sphincter. Non-peristaltic contractions were defined as the simultaneous onset of contraction waves recorded 3 or $5 \mathrm{~cm}$ apart. Reference values were obtained from nine healthy children (mean age \pm SD: $8.9 \pm 1.7$ years) undergoing esophageal manometry due to unconfirmed gastroesophageal reflux disease (control group).

Esophageal transit scintigraphy for detecting esophageal transit time was carried out using $10 \mathrm{ml}$ of water containing ${ }^{99 \mathrm{~m}} \mathrm{Tc}$ pertechnetate. All children were studied in the sitting position after a fast of at least $6 \mathrm{~h}$. The child was asked to swallow a single bolus and the progression of the bolus through the esophagus was monitored with a computerized gamma camera. Esophageal transit was considered to be normal when the entire radioactive bolus passed through the esophagus and entered the stomach in less than $8 \mathrm{~s}$, leaving no residual radioactivity in the esophageal area. Three scores were used in the presence of residual radioactivity (7): 1) slight esophageal transit delay $=$ residual activity less than $5 \%$ for more than $8 \mathrm{~s}$ and less than $15 \mathrm{~s} ; 2$ ) moderate esophageal transit delay $=$ less than $5 \%$ of residual activity for more than $15 \mathrm{~s}$ or more than $5 \%$ residual activity for less than $20 \mathrm{~s}$; 3) severe esophageal transit delay $=$ more than $5 \%$ residual activity for more than $20 \mathrm{~s}$.

Results are reported as means \pm SD. Data were analyzed statistically by the unpaired Student $t$-test or Fisher exact test, with the level of significance set at $5 \%$.

The Hospital Ethics Committee approved the study, and informed consent was obtained from the parents of all patients.

\section{Results}

The clinical and laboratory data of the patients are presented in Table 1. The mean of the interval from the accident to the functional studies was $4.6 \pm 2.6$ years. There was no association between severity of acute esophageal injury and late dysphagia ( $\mathrm{P}=$ 0.51, two tailed Fisher's exact test).

The results of lower esophageal sphincter pressure and contraction amplitude are also presented in Table 1. Lower esophageal sphincter relaxation was complete and coordinated with swallowing complexes in 17/21 patients. It was not possible to identify this event in 4 patients because of very low lower esophageal sphincter pressure (cases 2, 8, 12 , and 18). 
Table 1. Clinical data for 21 patients presenting esophageal strictures caused by sodium hydroxide ingestion.

\begin{tabular}{|c|c|c|c|c|c|c|c|c|}
\hline $\begin{array}{l}\text { Patient } \\
\text { No. }\end{array}$ & $\begin{array}{l}\text { Patient ages } \\
\text { (functional study/ } \\
\text { follow-up*) }\end{array}$ & $\begin{array}{l}\text { Acute } \\
\text { injury }\end{array}$ & $\begin{array}{l}\text { Complaint at } \\
\text { functional } \\
\text { study }\end{array}$ & $\begin{array}{c}\text { Esophageal } \\
\text { dilatation sessions } \\
\text { and frequency }\end{array}$ & $\begin{array}{c}\text { Stenosis } \\
\text { location and } \\
\text { length }(\mathrm{cm} / \%)\end{array}$ & $\begin{array}{l}\text { Esophageal } \\
\text { emptying }\end{array}$ & $\begin{array}{l}\text { Fundo- } \\
\text { plication }\end{array}$ & $\begin{array}{l}\text { Esophageal } \\
\text { manometry }\end{array}$ \\
\hline 1 & $4.7 / 1.8$ & S & $\begin{array}{c}\text { Solid } \\
\text { dysphagia }\end{array}$ & $\begin{array}{c}26 \\
(3 \text { weeks })^{* *}\end{array}$ & $\begin{array}{r}\text { Distal } / 5 \\
\mathrm{~cm} / 25 \%\end{array}$ & $\begin{array}{l}\text { Severe } \\
\text { delay }\end{array}$ & N & $\begin{array}{c}\text { Absent peristalsis and low-ampli- } \\
\text { tude contractions in esophageal } \\
\text { body, LESP }=12.88\end{array}$ \\
\hline 2 & $9.7 / 7.4$ & S & $\begin{array}{c}\text { Solid } \\
\text { dysphagia }\end{array}$ & $\begin{array}{c}27 \\
(4 \text { years })^{+}\end{array}$ & $\begin{array}{l}\text { Distal/2 } \\
\mathrm{cm} / 10 \%\end{array}$ & Normal & Y & $\begin{array}{l}\text { Segmental disorders in distal } \\
\text { segment, LESP }=5.9\end{array}$ \\
\hline 3 & $11 / 9.5$ & S & Asymptomatic & $16\left(8\right.$ months $^{+}$ & Distal/5cm/15\% & Normal & N & Normal, LESP $=12.80$ \\
\hline 4 & $12.2 / 9.5$ & M & $\begin{array}{c}\text { Solid } \\
\text { dysphagia }\end{array}$ & $\begin{array}{c}20 \\
\left(24 \text { months }^{+}\right.\end{array}$ & $\begin{array}{l}\text { Distal/1 } \\
\mathrm{cm} / 4 \%\end{array}$ & Normal & N & $\begin{array}{l}\text { Segmental disorders in middle } \\
\text { and distal segments, LESP }=13.60\end{array}$ \\
\hline 5 & $9.7 / 8.2$ & S & $\begin{array}{c}\text { Solid } \\
\text { dysphagia }\end{array}$ & $\begin{array}{c}37 \\
\text { (4 years) }\end{array}$ & M-D/25 cm/80\% & $\begin{array}{l}\text { Severe } \\
\text { delay }\end{array}$ & Y & $\begin{array}{c}\text { Absent peristalsis and low-ampli- } \\
\text { tude contractions in esophageal } \\
\text { body, LESP }=11.90\end{array}$ \\
\hline 6 & $15.5 / 2.1$ & S & $\begin{array}{c}\text { Solid } \\
\text { dysphagia }\end{array}$ & $\begin{array}{c}28 \\
(3 \text { weeks })^{* *}\end{array}$ & M-D/15 cm/40\% & $\begin{array}{l}\text { Severe } \\
\text { delay }\end{array}$ & Y & $\begin{array}{c}\text { Absent peristalsis and low-ampli- } \\
\text { tude contractions in esophageal } \\
\text { body, LESP }=11.90\end{array}$ \\
\hline 7 & $8.8 / 5.3$ & S & Asymptomatic & 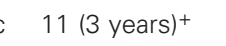 & Middle/2 cm/6\% & Normal & $\mathrm{N}$ & Normal, LESP $=10.50$ \\
\hline 8 & $5.9 / 4.7$ & M & Asymptomatic & $8\left(10\right.$ months $^{+}$ & $\mathrm{P}-\mathrm{M} / 1 \mathrm{~cm} / 4 \%$ & Normal & Y & $\begin{array}{l}\text { Segmental disorders in } \\
\text { proximal and middle segments, } \\
\qquad E S P=5.0\end{array}$ \\
\hline 9 & $4.8 / 1.5$ & S & $\begin{array}{c}\text { Solid } \\
\text { dysphagia }\end{array}$ & $\begin{array}{c}5 \\
(4 \text { weeks })^{* *}\end{array}$ & $\begin{array}{c}M-D / 6 \\
\mathrm{~cm} / 25 \%\end{array}$ & $\begin{array}{l}\text { Severe } \\
\text { delay }\end{array}$ & Y & $\begin{array}{c}\text { Absent peristalsis and low-ampli- } \\
\text { tude contractions in esophageal } \\
\text { body, LESP }=12.0\end{array}$ \\
\hline 10 & $4.3 / 2.9$ & S & $\begin{array}{c}\text { Solid } \\
\text { dysphagia }\end{array}$ & $\begin{array}{c}10 \\
(4 \text { weeks })^{* *}\end{array}$ & $\begin{array}{l}\text { Distal } / 4 \\
\mathrm{~cm} / 21 \%\end{array}$ & $\begin{array}{l}\text { Severe } \\
\text { delay }\end{array}$ & Y & $\begin{array}{c}\text { Absent peristalsis and low-ampli- } \\
\text { tude contractions in esophageal } \\
\text { body, LESP }=19.44\end{array}$ \\
\hline 11 & $7.5 / 5.3$ & S & $\begin{array}{c}\text { Solid } \\
\text { dysphagia }\end{array}$ & $\begin{array}{c}27 \\
(3 \text { years })^{+}\end{array}$ & $\begin{array}{c}M-D / 6 \\
\mathrm{~cm} / 23 \%\end{array}$ & $\begin{array}{l}\text { Severe } \\
\text { delay }\end{array}$ & Y & $\begin{array}{c}\text { Absent peristalsis and low-ampli- } \\
\text { tude contractions in esophageal } \\
\text { body, LESP }=9.13\end{array}$ \\
\hline 12 & $5.7 / 4.1$ & S & $\begin{array}{c}\text { Solid } \\
\text { dysphagia }\end{array}$ & $\begin{array}{c}50 \\
(3 \text { weeks) })^{* *}\end{array}$ & $\begin{array}{c}M-D / 5 \\
\mathrm{~cm} / 21 \%\end{array}$ & $\begin{array}{l}\text { Severe } \\
\text { delay }\end{array}$ & Y & $\begin{array}{c}\text { Absent peristalsis and low-ampli- } \\
\text { tude contractions in esophageal } \\
\text { body, LESP }=1.7\end{array}$ \\
\hline 13 & $7.3 / 5.7$ & $S$ & Asymptomatic & 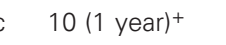 & Middle/3cm/4\% & Normal & Y & Normal, LESP $=14.70$ \\
\hline 14 & $8.2 / 6.9$ & S & Asymptomatic & $56(5 \text { years })^{+}$ & Middle/3 cm/10\% & Normal & N & Normal, LESP $=12.90$ \\
\hline 15 & $5.9 / 0.9$ & S & $\begin{array}{c}\text { Solid } \\
\text { dysphagia }\end{array}$ & $\begin{array}{c}11 \\
(3 \text { weeks })^{* *}\end{array}$ & $\begin{array}{r}\text { Distal/3 } \\
\mathrm{cm} / 10 \%\end{array}$ & Normal & Y & $\begin{array}{l}\text { Segmental disorders in middle } \\
\text { and distal segment, LESP }=7.94\end{array}$ \\
\hline 16 & $5.9 / 4.4$ & S & $\begin{array}{c}\text { Solid } \\
\text { dysphagia }\end{array}$ & $\begin{array}{c}12 \\
\left(2 \text { years }^{+}\right.\end{array}$ & $\begin{array}{r}\text { Distal } / 3 \\
\mathrm{~cm} / 10 \%\end{array}$ & Normal & Y & $\begin{array}{l}\text { Segmental disorders in distal } \\
\text { segment, LESP }=29.90\end{array}$ \\
\hline 17 & $6.6 / 5.3$ & S & $\begin{array}{c}\text { Liquid } \\
\text { dysphagia }\end{array}$ & $\begin{array}{c}50 \\
(6 \text { weeks })^{* *}\end{array}$ & $\begin{array}{l}\text { Distal/4 } \\
\mathrm{cm} / 25 \%\end{array}$ & $\mathrm{~Np}$ & Y & $\begin{array}{c}\text { Absent peristalsis and low-ampli- } \\
\text { tude contractions in esophageal } \\
\text { body, LESP }=19.10\end{array}$ \\
\hline 18 & $4.7 / 2.4$ & S & $\begin{array}{c}\text { Solid } \\
\text { dysphagia }\end{array}$ & $\begin{array}{c}22 \\
(3 \text { weeks })^{* *}\end{array}$ & & Moderate & & $\begin{array}{c}\text { Absent peristalsis and low-ampli- } \\
\text { tude contractions in esophageal } \\
\text { body, LESP }=4.90\end{array}$ \\
\hline 19 & $6.3 / 3.4$ & M & Asymptomatic & $\begin{array}{c}8 \\
(16 \text { months })^{+}\end{array}$ & $\begin{array}{l}\text { Distal } / 2 \\
\mathrm{~cm} / 8 \%\end{array}$ & Normal & Y & $\begin{array}{l}\text { Segmental disorders in distal } \\
\text { segments, LESP }=8.90\end{array}$ \\
\hline 20 & $4.7 / 1.7$ & S & $\begin{array}{c}\text { Solid } \\
\text { dysphagia }\end{array}$ & $\begin{array}{c}16 \\
(3 \text { weeks })^{* *}\end{array}$ & $\begin{array}{c}M-D / 6 \\
\mathrm{~cm} / 25 \%\end{array}$ & $\begin{array}{l}\text { Moderate } \\
\text { delay }\end{array}$ & Y & $\begin{array}{c}\text { Absent peristalsis and low-ampli- } \\
\text { tude contractions in esophageal } \\
\text { body, LESP }=29.00\end{array}$ \\
\hline 21 & $7.4 / 3.8$ & M & $\begin{array}{c}\text { Solid } \\
\text { dysphagia }\end{array}$ & $\begin{array}{c}22 \\
\left(29 \text { months }^{+}\right.\end{array}$ & $\begin{array}{l}\text { Distal/6 } \\
\mathrm{cm} / 25 \%\end{array}$ & $\begin{array}{l}\text { Moderate } \\
\text { delay }\end{array}$ & Y & $\begin{array}{c}\text { Absent peristalsis and low-ampli- } \\
\text { tude contractions in esophageal } \\
\text { body, LESP }=24.00\end{array}$ \\
\hline
\end{tabular}

*Follow-up refers to the period from accident to functional study; ${ }^{*}$ total number of dilatations performed in the past and current frequency; +total number of dilatation sessions performed in the past and total period of dilatation therapy. LESP $=$ lower esophageal sphincter pressure in mmHg; $\mathrm{M}-\mathrm{D}=$ middle and distal esophageal segments; $\mathrm{M}=$ moderate; $\mathrm{N}=$ non-operated; $\mathrm{Np}=$ not performed; $\mathrm{P}-\mathrm{M}=$ proximal and middle esophageal segments; $S=$ severe; $Y=$ operated. 
In 11 patients displaying long strictures ( $>20 \%$ of esophageal length), deglutition complexes also presented aperistalsis. The results of manometry recordings are presented in Table 1. Most of these recordings presented elevated basal pressure, low-amplitude waves and exaggerated transmission of aortic pulse (Figure 1A). Manometry data from this group were compared with the control group data and are presented in Table 2.

Data on esophageal manometry recordings from children who underwent fundoplication were compared to those from nonoperated children. The results related to esophageal body or lower esophageal sphincter pressure and upper esophageal sphincter pressure did not differ significantly between groups (Table 2).

Six patients presented esophageal motor abnormality characterized by low-amplitude, broad-based and double-peak contractions localized only in the constricted esophageal segment (Figure 1B). Four patients presented peristaltic contractions with mean amplitude and duration similar to the control group $(101 \pm 36.1$ and $97.9 \pm 23.7 \mathrm{mmHg}$, respectively; $\mathrm{P}>0.05)$. There was no significant difference in wave duration between these patients and controls $(1.7 \pm 0.9$ vs $1.6 \pm 0.1 \mathrm{~s}$, respectively; $\mathrm{P}>0.05)$.

Upper esophageal function was considered normal when compared to healthy controls. Upper esophageal sphincter pressure could be measured in 15 patients and the mean value was not different from the control group $(88.9 \pm 21.7 v s 80.2 \pm 16.7 \mathrm{mmHg}$, $\mathrm{P}>0.05)$. Normal coordination with the pharynx and complete relaxation occurred following swallowing. Six patients did not tolerate the water perfusion of the upper esophageal sphincter during the catheter pullthrough technique.

There was a significant association between the presence of dysphagia and abnormalities on manometry $(\mathrm{P}=0.02$, Fisher) and between dysphagia and scintigraphy results $(\mathrm{P}=0.01$, Fisher $)$. There was a strong association between esophageal transit delay and aperistalsis on manometry. Recordings on manometry which showed abnormalities localized in a portion of the esophageal body did not present a correlation with the scintigraphy findings $(\mathrm{P}=0.09)$.

The pathological study of esophageal segments from two children who underwent a

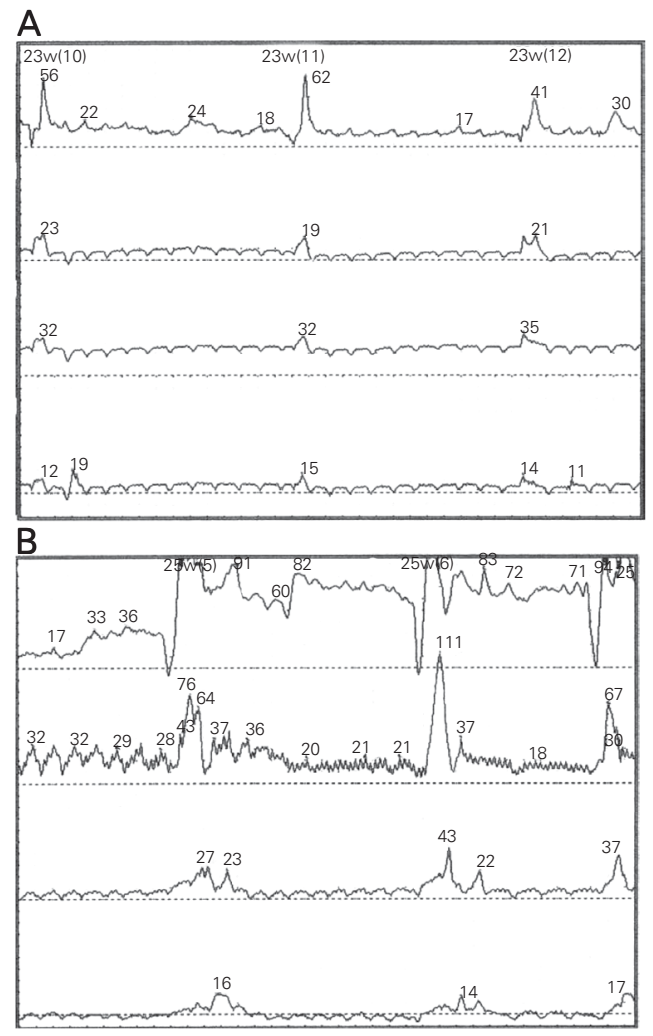

Figure 1. Manometry recording obtained at the level of the esophageal body after a 5-ml water swallow (W). Each record shows three deglutition complexes. Time elapsed between two dotted vertical lines $=4 \mathrm{~s}$. Each horizontal line indicates a pressure sensor placed $3 \mathrm{~cm}$ apart for patient 1 and $5 \mathrm{~cm}$ apart for patient 15. A, Patient number 1: low amplitude contractions and esophageal aperistalsis, elevated basal pressure, low-amplitude waves, and exaggerated transmission of aortic pulse. B, Patient number 15 : segmental disorders in middle and distal segment.
Table 2. Results of manometry, with comparison of the caustic group with absent peristalsis and the control group and between operated and non-operated children from the caustic group.

\begin{tabular}{lcccc}
\hline & $\begin{array}{c}\text { Caustic group } \\
\text { with absent } \\
\text { peristalsis } \\
(\mathrm{N}=11)\end{array}$ & $\begin{array}{c}\text { Control } \\
\text { group } \\
(\mathrm{N}=9)\end{array}$ & $\begin{array}{c}\text { Caustic } \\
\text { operated } \\
\text { group } \\
(\mathrm{N}=16)\end{array}$ & $\begin{array}{c}\text { Caustic } \\
\text { non-operated } \\
\text { group } \\
(\mathrm{N}=5)\end{array}$ \\
\hline Amplitude of waves $(\mathrm{mmHg})$ & $24.4 \pm 11.2^{*}$ & $97.9 \pm 23.7$ & $38.6 \pm 38.4$ & $54.6 \pm 19.7$ \\
Duration of waves (s) & $6.7 \pm 2.4^{*}$ & $1.6 \pm 0.1$ & $5.6 \pm 3.4$ & $4.9 \pm 4.2$ \\
LESP (mmHg) & $15.0 \pm 8.0$ & $15.1 \pm 1.7$ & $13.2 \pm 7.4$ & $12.5 \pm 1.2$ \\
UESP $(\mathrm{mmHg})$ & $78.4 \pm 26.8$ & $88.9 \pm 21.7$ & $89.9 \pm 34.1$ & $83.3 \pm 24.4$
\end{tabular}

Data are reported as means \pm SD. LESP $=$ lower esophageal sphincter pressure; UESP $=$ upper esophageal sphincter pressure. ${ }^{*} \mathrm{P}<0.05$ compared to control group (Student $t$-test). 
replacement procedure showed extensive fibrosis totally replacing the mucosal and submucosal layers and partially replacing the muscular layer. A histologically normal myenteric plexus was identified in all segments examined (Figure 2).

\section{Discussion}

Alkali ingestion in childhood is usually accidental and involves smaller amounts than those ingested by adults with a suicidal intent. However, esophageal injuries are equally deep and result in strictures in about $30 \%$ of all accidents (8-10). Recent studies have reported motor dysfunction after second- or third-degree burns and complete absence of peristalsis, and low-amplitude waves after swallows were found in $70 \%$ of recordings on manometry $(5,11)$. Low-amplitude aperistaltic contractions and narrowing and
A

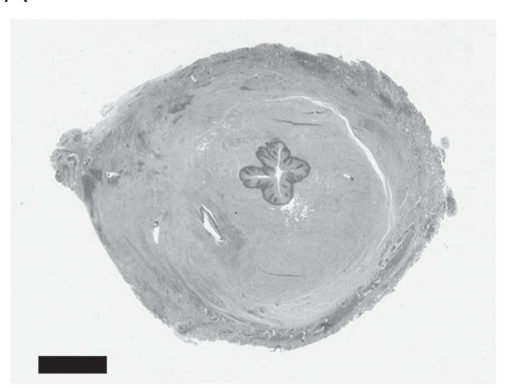

C

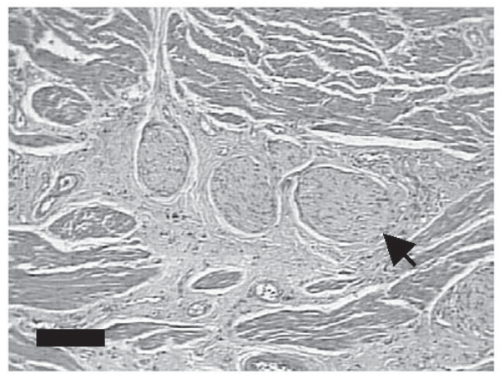

B

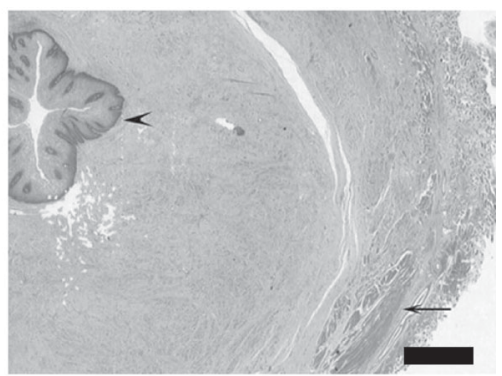

D

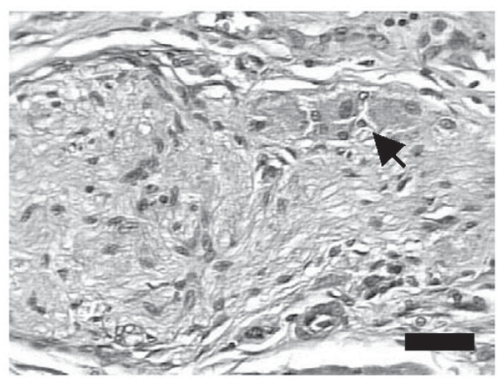

Figure 2. Histological analysis of the esophagus from a patient submitted to esophageal replacement. A, Esophagus showing stenosis of the lumen and extensive fibrosis that compromised the mucosa, submucosa and partially the muscular layer (HE 10X, bar = $1650 \mu \mathrm{m})$. B, Detail of $A$. Extensive fibrosis replacing almost all the normal components of the esophageal wall from the epithelium (arrowhead) to the external muscular layer (arrow; $\mathrm{HE} 32 \mathrm{X}$, bar $=484 \mu \mathrm{m})$. $C$ and $D$, Details of $A$. Note the preserved myenteric plexus (arrow; $\mathrm{HE} 132 \mathrm{X}$, bar $=200 \mu \mathrm{m}$ and $330 \mathrm{X}$, bar $=50 \mu \mathrm{m})$. shortening of the esophagus have been considered to account for impaired esophageal motor function (5,6,11-13). These studies indicated that development of esophageal stricture, impaired motility, and gastroesophageal reflux are very frequent outcomes of caustic esophageal burns and should be considered when evaluating symptoms and defining therapeutic strategies. The children in the present series continued to display dysphagia even after being discharged from dilatation therapy, as also reported by Bautista et al. (5), who concluded that the patients' complaints do not always correspond to the degree of severity of the stenosis but indicate disturbances of esophageal motility.

Esophageal dysmotilities were observed frequently in our series and the severity of complaints was associated with scintigraphy and manometry findings. Scintigraphy is considered to be the most reliable procedure for evaluating esophageal motility (14-17). However, manometry is considered to be more sensitive to identify nonspecific abnormalities in patients with non-cardiac chest pain (18). In the present study, all subjects with esophageal transit delay had absent peristalsis on manometry, but there was no significant correlation between the presence of non-generalized abnormalities and esophageal transit delay, probably reflecting the lower accuracy of scintigraphy in identifying abnormalities limited to a part of the esophagus. A previous report demonstrated that delayed esophageal emptying is associated with aperistalsis more than with any other esophageal motor abnormality (17).

We found that length of the cicatricial replacement of mucosa was significantly associated with absent peristalsis, esophageal transit delay, and dysphagia. The anatomopathological basis of the esophageal motor abnormalities in the chronic phases of caustic esophagitis is under discussion. The depth of penetration into tissue by the alkaline agents has been demonstrated experimentally $(2,19)$. Tissue penetration with lique- 
factive necrosis is followed by destruction of the epithelium and submucosa with intense inflammation, and in severe burns inflammation may extend through the muscle layer. Impaired esophageal motility may be the result of fibrotic structure, shortened esophagus, and reduction in neuron number in the myenteric plexus $(5,11)$. The large number of dilatations is also implicated as a factor leading to tissue injury and dysmotility (11). In two children from our series treated with esophageal replacement, histological examination showed extensive fibrosis compromising the mucosa, submucosa and partially the muscularis layers. The internal muscular layer was the most affected by fibrosis, but the myenteric plexus was present and preserved. The close association between the length of mucosal fibrosis and the findings on manometry indicates that dysphagia is more the result of a restrictive effect of the scarred tissue on muscle contractility than of damage to the functional integrity of the motor myenteric plexus. Our manometry recordings showed complete and coordinate lower esophageal sphincter relaxation in most patients with aperistalsis and in all those with localized abnormalities, suggesting adequate function of the myenteric plexus.

Although previous studies have shown that lower esophageal sphincter failure does not occur in subjects with esophageal caustic burns $(5,6), 15$ patients from the present series had a lower esophageal sphincter pressure below the mean $\pm \mathrm{SD}$ value in the control group. A severely burned esophagus becomes narrower and also shorter compared with its original shape (19), compromising the length of the intraabdominal esophageal segment. The length of the intraabdominal esophageal segment has been identified as an important factor in proper functioning of the lower esophageal sphincter (20).

Peptic inflammation repeatedly triggers stricture formation, impairing the outcome of caustic esophageal strictures (13) and may be also a different factor impairing esophageal motility (21).

Children with severe caustic strictures often need a large number of dilatations over long periods of time. In the long run, this may be associated with anesthetic-related toxicity and an increase risk of complications. Predicting which children would suffer from persistent dysphagia and would need esophageal replacement might help obviate the need for a long period of useless dilatation procedures. Further studies are needed to confirm the suggested association between length of injury and final outcome.

The present data show that ingestion of caustic substances by children may produce severe chronic esophageal damage that leads to disturbances of esophageal motility which are related to the length of mucosal fibrosis. Involvement of more than $20 \%$ of the esophagus length may be associated with persistent dysphagia.

\section{References}

1. Montano A, Delgado L, Iglesias C, Tanzi MN, Armas D, Acosta A, Sereno V \& Mendez V (2001). Endoscopia de urgencia: Casuística del servicio de endoscopia pediátrica del centro Hospitalario Pereira Rossell. Annals of the XIV Latin-American Congress of Pediatric Gastroenterology and Nutrition, Buenos Aires, Argentina, 168.

2. Haller Jr JA, Andrews HG, White JJ, Tamer MA \& Cleveland WW (1971). Pathophysiology and management of acute corrosive burns of the esophagus: results of treatment in 285 children. Journal of Pediatric Surgery, 6: 578-584.

3. Wasserman RL \& Ginsburg CM (1985). Caustic substance injuries.
Journal of Pediatrics, 107: 169-174.

4. Servidoni MFCP, Cardoso SR, Brandão MAB, Monteiro A, De Tommaso AM, Santos DSM, Silva PA \& Barroso PR (2001). Avaliação do serviço de endoscopia pediátrica do HC/UNICAMP - 10 anos (1991-2000). Annals of the X Brazilian Congress of Pediatric Gastroenterology, Brasília, DF, Brazil, May 5-8, 2001, 69.

5. Bautista A, Varela R, Villanueva A, Estevez E, Tojo R \& Cadranel S (1996). Motor function of the esophagus after caustic burn. European Journal of Pediatric Surgery, 6: 204-207.

6. Cadranel S, Di Lorenzo C, Rodesch P, Piepsz A \& Ham HR (1990). 
Caustic ingestion and esophageal function. Journal of Pediatric Gastroenterology and Nutrition, 10: 164-168.

7. Ham HR, Georges B, Froideville JL \& Piepsz A (1985). Oesophageal transit of liquid: effects of single or multiple swallows. Nuclear Medicine Communications, 6: 263-267.

8. Gupta SK, Croffie JM \& Fitzgerald JF (2001). Is esophagogastroduodenoscopy necessary in all caustic ingestion? Journal of Pediatric Gastroenterology and Nutrition, 32: 50-53.

9. Nunes AC, Romaozinho JM, Pontes JM, Rodrigues V, Ferreira M, Gomes D \& Freitas D (2002). Risk factors for stricture development after caustic ingestion. Hepato-Gastroenterology, 49: 1563-1566.

10. Mamede RC \& De Mello Filho FV (2002). Treatment of caustic ingestion: an analysis of 239 cases. Diseases of the Esophagus, 15: 210-213.

11. Dantas RO \& Mamede RC (1996). Esophageal motility in patients with esophageal caustic injury. American Journal of Gastroenterology, 91: 1157-1161.

12. Genç A \& Mutaf O (2002). Esophageal motility changes in acute and late periods of caustic esophageal burns and their relation to prognosis in children. Journal of Pediatric Surgery, 37: 1526-1528.

13. Mutaf $O$, Genç A, Hereko O, Demircan M, Ozcan C \& Arikan A (1996). Gastroesophageal reflux: a determinant in the outcome of caustic esophageal burns. Journal of Pediatric Surgery, 31: 14941495.

14. Tolin RD, Malmud LS, Reilley J \& Fischer RS (1979). Esophageal scintigraphy to quantitate esophageal transit (quantitation of esophageal transit). Gastroenterology, 76: 1402-1408.
15. Russell CO, Hill LD, Holmes 3rd ER, Hull DA, Gannon R \& Pope 2nd CE (1981). Radionuclide transit: a sensitive screening test for esophageal dysfunction. Gastroenterology, 80: 887-892.

16. Blackwell JN, Hannan WJ, Adam RD \& Heading RC (1983). Radionuclide transit studies in the detection of esophageal dysmotility. Gut, 24: 421-426.

17. Richter JE, Blackwell JN, Wu WC, Johns DN, Cowan RJ \& Castell DO (1987). Relationship of radionuclide liquid bolus transport and esophageal manometry. Journal of Laboratory and Clinical Medicine, 109: 217-224

18. Mughal MM, Marples M \& Bancewicz J (1986). Scintigraphic assessment of esophageal motility: what does it show and how reliable is it? Gut, 27: 946-953.

19. Bautista A, Tojo R, Varela R, Estevez E, Villanueva A \& Cadranel S (1996). Effects of prednisolone and dexamethasone on alkali burns of the esophagus in rabbit. Journal of Pediatric Gastroenterology and Nutrition, 22: 275-283.

20. Bonavina L, Evander A, DeMeester TR, Walther B, Cheng SC, Palazzo L \& Concannon JL (1986). Length of the distal esophageal sphincter and competency of the cardia. American Journal of Surgery, 151: 25-34

21. Kasapidis P, Xynos E, Mantides A, Chrysos E, Demonakou M, Nikolopoulos N \& Vassilakis JS (1993). Differences in manometry and 24-h ambulatory $\mathrm{pH}$-metry between patients with and without endoscopic or histological esophagitis in gastroesophageal reflux disease. American Journal of Gastroenterology, 88: 1893-1899. 